\title{
Pemetaan Kedudukan dan Materi Muatan Peraturan Mahkamah Konstitusi
}

\author{
Rudy, dan Reisa Malida
}

\section{Dosen Bagian Hukum Tata Negara FH Unila \\ Mahasiswa Bagian HTN angkatan 2009}

\begin{abstract}
Abstrak
Penelitian ini bertujuan untuk memetakan kedudukan dan materi muatan Peraturan Mahkamah Konstitusi (PMK) dalam sistem peraturan perundangundangan di Indonesia. Penelitian ini menggunakan studi normatif yang menggunakan batu uji kelembagaan negara. Penelitian ini menemukan bahwa kedudukan PMK harus ditinjau dari aspek kelembagaan negara sehingga bisa disimpulkan bahwa kedudukan PMK setingkat dengan Peraturan Presiden. Selain itu, penelitian ini menghasilkan pemetaan materi muatan yang harus diatur dalam PMK.
\end{abstract}

\section{Pendahuluan}

Perubahan Ketiga UndangUndang Dasar 1945 (UUD Tahun 1945) telah melahirkan sebuah lembaga baru dengan kewenangan khusus yang merupakan salah satu bentuk judicial control dalam kerangka sistem checks and balances diantara cabang-cabang kekuasaan pemerintahan. ${ }^{1}$ Lembaga tersebut merupakan salah satu lembaga negara yang bergerak di dalam ranah penyelenggaraan kekuasaan kehakiman di Indonesia, selain Mahkamah Agung dan badan peradilan yang berada dibawahnya, yaitu lembaga Mahkamah Konstitusi, melalui UUD Tahun 1945 Pasal 24 ayat (2), yang menyatakan :

Kekuasaan

kehakiman dilakukan oleh sebuah Mahkamah Agung dan badan peradilan yang berada di bawahnya dalam lingkungan peradilan umum, lingkungan peradilan agama,

1 Bandingkan: Maruarar Siahaan, Hukum Acara Mahkamah Konstitusi Republik Indonesia, (Jakarta: Sinar Grafika, 2011), hlm. 1. lingkungan peradilan militer, lingkungan peradilan tata usaha negara, dan oleh sebuah Mahkamah Konstitusi".

Penjelasan Undang-Undang Nomor 23 Tahun 2004 tentang Mahkamah Konstitusi ${ }^{2}$ sebagaimana yang telah dirubah melalui UndangUndang Nomor 8 Tahun 2011 tentang Perubahan Atas UndangUndang Nomor 23 tahun 2004 tentang Mahkamah Konstitusi ${ }^{3}$ mengatur bahwa Mahkamah Konstitusi adalah salah satu pelaku kekuasaan kehakiman yang berfungsi menangani perkara tertentu di bidang ketatanegaraan dalam rangka menjaga konstitusi agar dilaksanakan secara bertanggungjawab sesuai dengan kehendak rakyat dan cita-cita demokrasi.

Selain itu, Mahkamah Konstitusi juga merupakan tempat bagi warga masyarakat pencari keadilan atau justitiabelen (justice

2 Lembaran Negara Republik Indonesia (LNRI) Tahun 2003 Nomor 98, Tambahan Lembaran Negara Republik Indonesia (TLNRI) Nomor 4958.

${ }^{3}$ LNRI Tahun 2011 Nomor 70 
seekers) dalam mencari keadilan sesuai dengan tugas dan wewenang Mahkamah Konstitusi yang termaktub di dalam UUD Tahun 1945 yaitu pasal 24C ayat (1). ${ }^{4}$ Kewenangan tersebut pada perkembangannya ditambah lagi dengan kewenangan untuk memutus perselisihan hasil Pemilukada berdasarkan UU Nomor 12 Tahun 2008 tentang Perubahan Kedua UU Nomor 32 Tahun 2004 tentang Pemerintahan Daerah ${ }^{5}$ Pasal 236C ayat (1). ${ }^{6}$

Dalam rangka menjalankan fungsi kekuasaan kehakiman atau fungsi peradilan (rechtsprekende functie) tersebut, Mahkamah Konstitusi kemudian mengatur mengenai pedoman beracara di Mahkamah Konstitusi yang ditujukan bagi masyarakat umum sebagai subjek-subjek hukum (legal subjects) yang tengah beracara di Mahkamah Kontitusi dan hal-hal lainnya melalui Peraturan Mahkamah Konstitusi (PMK). Terdapat beberapa ketimpangan yang patut untuk

\footnotetext{
${ }^{4}$ Empat kewenangan Mahkamah Konstitusi tersebut, yaitu Mahkamah Konstitusi berwenang mengadili pada tingkat pertama dan terkahir yang putusannya bersifat final untuk :

1. Menguji undang-undang terhadap Undang-Undang Dasar;

2. Memutus sengketa kewenangan lembaga negara yang kewenangannya diberikan oleh Undang-Undang Dasar;

3. Memutus pembubaran partai politik;

4. Memutus perselisihan tentang hasil pemilihan umum.

${ }^{5}$ LNRI Tahun 2008 Nomor 59.

${ }^{6}$ Menyatakan bahwa :

"Penanganan sengketa hasil penghitungan suara pemilihan kepala daerah dan wakil kepala daerah oleh Mahkamah Agung dialihkan kepada Mahkamah Konstitusi paling lama 18 (delapan belas) bulan sejak Undang-Undang ini diundangkan.”
}

diperhatikan dalam hal pengaturan PMK ini, antara lain:

1. PMK yang secara teori seharusnya hanya bersifat dan berlaku bagi internal kelembagaan, namun pada kenyataan ternyata norma yang terkandung di dalam PMK banyak yang bersentuhan langsung dengan subjek-subjek hukum di luar Mahkamah Konstitusi, yaitu pada pedoman beracara di Mahkamah Konstitusi;

2. Pembentukan PMK yang didasarkan pada ketentuan dalam Pasal 86 UU Mahkamah Konstitusi merupakan norma penyempurna dari ketidaklengkapan UU Mahkamah Konstitusi, serta atas dasar pembentukan yang dinilai terburu-buru. ${ }^{7}$ Namun, setelah hampir satu dasawarsa Mahkamah Konstitusi berdiri, berdasarkan kedua alasan tersebut dapat dijadikan kajian mengenai kelayakan terus dipertahankannya pedoman beracara yang diatur dengan PMK; serta

3. Peraturan-peraturan yang dikeluarkan oleh lembagalembaga negara, khususnya PMK, walaupun telah diakui keberadaannya namun ternyata tidak diketahui letak kedudukannya didalam hierarki peraturan perundang-undangan, sejajar dengan undang-undang atau dibawah undang-undang. Terlebih lagi mengingat PMK memiliki materi muatan yang berlaku diluar lembaga.

Berdasarkan ketimpanganketimpangan yang telah diuraikan di atas sudah menjadi keharusanlah untuk diadakannya kajian mengenai

\footnotetext{
${ }^{7}$ Ibid.
} 
kedudukan PMK berdasarkan teori Hukum Tata Negara dan Teori Perundang-undangan.

\section{Pembahasan}

\section{Kedudukan Peraturan Mahkamah Konstitusi (PMK) dalam Hierarki Peraturan Perundang-Undangan}

Undang-Undang Dasar Tahun 1945 sebelum dan sesudah perubahan tidak menetapkan dalam pasal-pasalnya tentang kedudukan atau hierarki peraturan perundanundangan di Indonesia. Selain itu UUD Tahun 1945 hanya menetapkan secara tegas beberapa jenis peraturan perundang-undangan, yaitu UndangUndang, Peraturan Pemerintah Pengganti Undang-undang, dan Peraturan Pemerintah. Jenis dan hierarki perundang-undangan kemudian ditegaskan melalui undang-undang, yaitu UndangUndang Nomor 10 Tahun 2004 tentang Pembentukan Peraturan Perundang-undangan. Namun kemudian, Undang-Undang tersebut telah digantikan oleh UndangUndang Nomor 12 Tahun 2011 tentang Pembentukan Peraturan Perundang-Undangan yang berlaku saat ini.

Untuk menganalisis mengenai kedudukan PMK dalam hierarki Peraturan Perundang-Undang peneliti akan menjabarkan terlebih dahulu kedudukan PMK berdasarkan kedua undang-undang tersebut.

\section{Kedudukan PMK Berdasarkan Undang-Undang Nomor 10 Tahun 2004}

Pengaturan mengenai hierarki peraturan perundangan diatur didalam Pasal 7 ayat (1) UndangUndang Nomor 10 Tahun 2004 tentang Pembentukan Peraturan Perundang-undangan. Pasal 7 ayat
(1) ini menjelaskan mengenai jenis dan hierarki Peraturan Perundangundangan adalah sebagai berikut:

1. Undang-Undang Dasar Negara Republik Indonesia Tahun 1945;

2. Undang-Undang/Peraturan

Pemerintah Pengganti UndangUndang;

3. Peraturan Pemerintah;

4. Peraturan Presiden;

5. Peraturan Daerah.

Adapun jenis peraturan perundang-undangan selain yang disebutkan Pasal 7 ayat (1) tersebut diakui keberadaannya dan mempunyai kekuatan hukum mengikat sepanjang diperintahkan oleh peraturan perundang-undangan yang lebih tinggi. Ketentuan ini diatur di dalam Pasal 7 ayat (4) UU Nomor 10 Tahun 2004. Undangundang ini, tidak memasukkan jenis peraturan yang dimaksud dalam Pasal 7 ayat (4) tersebut. Namun demikian, jenis peraturan perundangundangan yang dimaksud dalam pasal 7 ayat 4 tersebut di sebutkan secara rinci dalam Penjelasan Pasal 7 ayat (4) Undang-Undang Nomor 10 Tahun 2004 tersebut.

Penjelasan atas Pasal 7 ayat (4) Undang-Undang Nomor 10 Tahun 2004 menyebutkan bahwa:

Jenis Peraturan Perundangundangan selain dalam ketentuan ini, antara lain, peraturan yang dikeluarkan oleh Majelis Permusyawaratan Rakyat dan Dewan Perwakilan Rakyat Dewan Perwakilan Daerah, Mahkamah Agung, Mahkamah Konstitusi, Badan Pemeriksa Keuangan, Bank Indonesia, Menteri, kepala badan, lembaga, atau komisi yang setingkat yang dibentak oleh undang-undang atau pemerintah atas perintah undang-undang, Dewan Perwakilan Rakyat Daerah Provinsi, Gubernur, Dewan Perwakilan Rakyat Daerah 
Kabupaten/Kota, Bupati/Walikota, Kepala Desa atau yang setingkat.

Selanjutnya melalui Pasal 5 di dalam undang-undang ini, hanya menerangkan bahwa Kekuatan hukum Peraturan Perundangundangan adalah sesuai dengan hierarki sebagaimana dimaksud pada ayat (1). Dan melalui Penjelasan ayat (5) menyebutkan bahwa dalam ketentuan ini yang dimaksud dengan "hierarki" adalah penjenjangan setiap jenis Peraturan Perundang-undangan yang didasarkan pada asas bahwa peraturan perundang-undangan yang lebih rendah tidak boleh bertentangan dengan Peraturan Perundang-undangan yang lebih tinggi. Sehingga, dengan berlakunya Undang-Udang nomor 10 Tahun 2004 ini, ternyata tidak menerangkan mengenai kedudukan PMK di dalam hierarki Peraturan Perundangundangan yang berlaku di Indonesia.

\section{Kedudukan PMK Berdasarkan UU Nomor 12 Tahun 2011}

Undang-Undang Nomor 12 tahun 2011 merupakan undangundang yang menggantikan UndangUndang nomor 10 Tahun 2004 tentang Pembentukan Peraturan Perundang-undangan. Undangundang ini mengatur mengenai jenis dan hierarki peraturan perundangundangan melalui Pasal 7 ayat (1). Pasal 7 ayat (1) dalam undangundang ini berisi bahwa jenis dan hierarki peraturan perundangundangan terdiri atas:

1. Undang-undang Dasar Negara Republik Indonesia Tahun 1945;

2. Ketetapan Majelis Permusyawaratan Rakyat;

3. Undang-undang/Peraturan Pemerintah Pengganti Undangundang;

4. Peraturan Pemerintah;

5. Peraturan Presiden;
6. Peraturan Daerah Provinsi; dan

7. Peraturan Daerah Kabupaten/Kota.

Undang-Undang Nomor 12 Tahun 2011 melalui Pasal 7 ayat (2) juga menetapkan bahwa kekuatan hukum Peraturan Perundangundangannya telah ditetapkan yaitu sesuai dengan hierarki tersebut. Undang-Undang ini kemudian juga menerangkan melalui Pasal 8 ayat (1), bahwa jenis peraturan perundang-undangan selain sebagaimana dimaksud diatas yaitu mencakup peraturan yang ditetapkan oleh Majelis Permusyawaratan Rakyat, Dewan Perwakilan Rakyat, Dewan Perwakilan Daerah, Mahkamah Agung, Mahkamah Konstitusi, Badan Pemeriksa Keuangan, Komisi Yudisial, Bank Indonesia, Menteri, badan, lembaga, atau komisi yang setingkat yang dibentuk dengan Undang-undang atau Pemerintah atas perintah Undang-undang, Dewan Perwakilan Rakyat Daerah Provinsi, Gubernur, Dewan Perwakilan Rakyat Daerah Kabupaten/Kota, Bupati/Walikota, Kepala Desa atau yang setingkat.

Pasal 8 ayat (2) menerangkan bahwa keberadaan peraturan perundang-undangan sebagaimana dimaksud diatas diakui keberadaannya dan mempunyai kekuatan hukum mengikat sepanjang diperintahkan oleh Peraturan Perundang-undangan yang lebih tinggi atau dibentuk berdasarkan kewenangan.

Sama halnya dengan undangundang sebelumnya, keberadaan Undang-Undang Nomor 12 Tahun 2011 ini tidak menjawab mengenai kedudukan PMK dalam hierarki peraturan perundang-undangan di Indonesia. 
Untuk menjawab permasalahan mengenai kedudukan PMK dalam hierarki peraturan perundangundangan, peneliti menganalisisnya melalui struktur kelembagaan dari Lembaga Negara yang berwenang mengeluarkan PMK.

\section{Analisis Kedudukan PMK dalam Hierarki Peraturan Perundang- Undangan \\ Undang-Undang Nomor 10}

Tahun 2004 tentang Pembentukan Peraturan Perundang-Undangan yang kemudian digantikan dengan Undang-Undang Nomor 12 Tahun 2011 memiliki kesamaan yang mendasar. Kedua Undang-undang tersebut, walaupun sama-sama mengakui keberadaan PMK dalam Sistem Hukum di Negara Republik Indonesi namun keduanya samasama tidak mencantumkan kedudukan PMK dalam hierarki peraturan perundang-undangan.

Selain itu, dari kedua undangundang ini terdapat perbedaan yang prinsipil pula. Perbedaan tersebut adalah melalui Undang-Undang nomor 12 Tahun 2012, pengakuan keberadaan PMK menjadi lebih tegas dalam hierarki peraturan perundang undangan ataupun dalam Sistem Hukum di Negara Republik Indonesia. Di dalam Undang-Undang Nomor 12 Tahun 2011, kedudukan peraturan lain, termasuk di dalamnya terdapat PMK, dituliskan di dalam batang tubuh Undang-undang tersebut, yaitu di dalam Pasal 8 ayat (1). Sedangkan di dalam UndangUndang Nomor 10 Tahun 2004, pengaturan mengenai peraturan lain, termasuk PMK, hanya terdapat di dalam Penjelasan atas UndangUndang Nomor 10 Tahun 2004, yaitu pada Penjelasan atas Pasal 7 ayat (4). Dimasukkannya UndangUndang Nomor 12 Tahun 2011 ternyata tidak mampu menjawab dengan jelas mengenai kedudukan PMK, sehingga kedua peraturan tersebut masih menimbulkan kerancuan dan perbedaan pemahaman. Untuk menjawab kedudukan PMK dalam hierarki peraturan perundang-undangan tersebut, peneliti kemudian melakukan peninjauan dari struktur kelembagaan negara.

Mahkamah Konstitusi sebagai lembaga yang berwenang mengeluarkan PMK, adalah termasuk ke dalam lembaga tinggi negara karena pembentukannya dibentuk oleh UUD Tahun 1945. Berdasarkan hal tersebut, tentu saja Mahkamah Konstitusi memiliki derajat kelembagaan yang lebih tinggi dibandingkan dengan lembaga negara lain yang pembentukannya dibentuk oleh Undang-Undang atau peraturan lain di bawah undangundang. Hal tersebut tentu saja berimplikasi pada kedudukan produk hukum yang dikeluarkan oleh Mahkamah Konstitusi, termasuk didalamnya PMK.

Produk hukum yang dihasilkan oleh lembaga tinggi negara tentu saja memliki hierarki peraturan perundang-undangan yang dibawah Undang-Undang/Peraturan

Pemerintah Pengganti UndangUndang. Seperti yang telah dipaparkan di dalam Tinjauan Pustaka, bahwa berdasarkan Pasal 11 Undang-Undang Nomor 12 Tahun 2011, bahwa materi muatan Peraturan Pemerintah Pengganti Undang- Undang sama dengan materi muatan Undang-Undang. Sedangkan untuk menajalankannyanya diperlukan Peraturan Pemerintah. Materi muatan Peraturan Pemerintah sendiri berisi materi untuk menjalankan UndangUndang sebagaimana mestinya. 
PMK sebagai salah satu produk hukum dari lembaga Mahkamah Konstitusi, memiliki tingkat hierarki yang sejajar dengan Peraturan Presiden. Hal ini karena materi muatan Peraturan Presiden sendiri berisi materi yang diperintahkan oleh Undang-Undang, sama halnya dengan PMK yang materinya diperintahkan oleh Undang-Undang Mahkamah Konstitusi, melalui Pasal 86 Undang-Undang Nomor 24 Tahun 2003 tentang Mahkamah Konstitusi jonto Undang-Undang Nomor 8 tahun 2011 tentang Perubahan Atas Undang-Undang Nomor 24 Tahun 2003 tentang Mahkamah Konstitusi.

Maka, berdasarkan analisis kedudukan kelembagaan negara tersebut, penulis menyimpulkan bahwa kedudukan PMK dalam hierarki peraturan perundangundangan, yaitu PMK memiliki kedudukan yang berada dibawah Peraturan Pemerintah dan sejajar dengan Peraturan Presiden.

\section{Pemetaan PMK berdasarkan} Materi Muatan Peraturan
Perundang-Undangan

Dalam sub-bab ini penulis akan mencoba memetakan PMK berdasarkan materi muatan yang terkadung di dalam PMK. Sebagai bahan pembanding, terlebih dahulu Peneliti paparkan tabel PMK yang telah dikeluarkan oleh Mahkmah Konstitusi sejak berdiri hingga saat ini sebagaimana terdapat dalam tabel 1.

Tabel 1

Peraturan Mahkamah Konstitusi 2005-2010

\begin{tabular}{|l|l|}
\hline No & PERATURAN MAHKAMAH KONSTITUSI (PMK) \\
\hline 1 & $\begin{array}{l}\text { Nomor 01/PMK/2003 tentang Tata Cara Pemilihan Ketua dan Wakil Ketua } \\
\text { Mahkamah Konstitusi. }\end{array}$ \\
\hline 2 & $\begin{array}{l}\text { Nomor 02/PMK/2003 tentang Kode Etik dan Pedoman Tingkah Laku Hakim } \\
\text { Konstitusi. }\end{array}$ \\
\hline 3 & $\begin{array}{l}\text { Nomor 03/PMK/2003 tentang Tata Tertib Persidangan Pada Mahkamah } \\
\text { Konstitusi republik Indonesia. }\end{array}$ \\
\hline 4 & $\begin{array}{l}\text { Nomor 04/PMK/2004 tentang Pedoman Beracara Dalam Perselisihan Hasil } \\
\text { Pemilihan Umum. }\end{array}$ \\
\hline 5 & $\begin{array}{l}\text { Nomor 05/PMK/2004 tentang Prosedur Pengajuan Keberatan Atas Penetapan } \\
\text { Hasil Pemilihan Umum Presiden dan Wakil Presiden Tahun 2004. }\end{array}$ \\
\hline 6 & $\begin{array}{l}\text { Nomor 06/PMK/2005 tentang pedoman Beracara Dalam Perkara Pengujian } \\
\text { Undang-Undang. }\end{array}$ \\
\hline 7 & $\begin{array}{l}\text { Nomor 07/PMK/2005 Tentang Pemberlakuan Deklarasi Kode Etik Dan } \\
\text { Perilaku Hakim Konstitusi. }\end{array}$ \\
\hline 8 & $\begin{array}{l}\text { Nomor 08/PMK/2006 Tentang Pedoman Beracara Dalam Sengketa } \\
\text { Kewenangan Konstitusional Lembaga Negara. }\end{array}$ \\
\hline 9 & $\begin{array}{l}\text { Komor 11/PMK/2006 Tentang Pedoman Administrasi Yustisial Mahkamah } \\
\text { Konstitusi. }\end{array}$ \\
\hline 10 & $\begin{array}{l}\text { Nomor 12/PMK/2008 tentang Pedoman Beracara dalam Pembubaran Partai } \\
\text { Politik. }\end{array}$ \\
\hline 11 & $\begin{array}{l}\text { Nomor 14/PMK/2008 tentang Pedoman Beracara dalam Perselisihan Hasil } \\
\text { Pemilihan Umum Anggota Dewan Perwakilaran Rakyat, Dewan Perwakilan } \\
\text { Daerah, dan Dewan Perwakilan Rakyat Daerah. }\end{array}$ \\
\hline 12 & $\begin{array}{l}\text { Nomor 15/PMK/2008 Tentang Pedoman Beracara dalam Perselisihan Hasil } \\
\text { Pemilihan Umum Kepala Daerah. }\end{array}$ \\
\hline
\end{tabular}




\begin{tabular}{|l|l|}
\hline 13 & $\begin{array}{l}\text { Nomor 16/PMK/2009 Tentang Pedoman Beracara dalam Perselisihan Hasil } \\
\text { Pemilihan Umum Anggota Dewan Perwakilaran Rakyat, Dewan Perwakilan } \\
\text { Daerah, dan Dewan Perwakilan Rakyat Daerah. }\end{array}$ \\
\hline 14 & $\begin{array}{l}\text { Nomor 17/PMK/2009 Tentang Pedoman Beracara Dalam Perselisihan Hasil } \\
\text { Pemilihan Umum Presiden dan Wakil Presiden. }\end{array}$ \\
\hline 15 & $\begin{array}{l}\text { Nomor 18/PMK/2009 Tentang Pedoman Pengajuan Permohonan Elektronik } \\
\text { (Electronic Filing) dan Pemeriksaan Persidangan Jarak Jauh (Video } \\
\text { Conference). }\end{array}$ \\
\hline 16 & $\begin{array}{l}\text { Nomor 19/PMK/2009 tentang Tata Tertib Persidangan. } \\
\text { Nomor 21/PMK/2009 tentang Pedoman Beracara dalam Memutus Pendapat } \\
\text { dewan Perwakilan Rakyat mengenai dugaan pelanggaran oleh Presiden } \\
\text { dan/atau Wakil Presiden. }\end{array}$ \\
\hline
\end{tabular}

Sumber: diolah dari http://www.mahkamahkonstitusi.go.id//

Hal yang perlu diingat sebelum memetakan peraturan-peraturan Mahkamah Konstitusi tersebut, yaitu bahwa tidak semua PMK memiliki materi muatan yang sama. Ada beberapa PMK yang murni memiliki materi PMK, namun ada pula yang materinya justru bermuatan UU. Hal ini dapat dilihat dari sifat keberlakuan PMK itu sendiri, yaitu ada yang bersifat internal kelembagaan Mahkamah Konstitusi dan ada pula yang bersifat eksternal.

Apabila ditinjau berdasarkan Pasal 10 UU Nomor 12 Tahun 2011 mengenai materi muatan yang harus diatur dengan Undang-Undang, beberapa PMK yang terkait dengan pedoman beracara di Mahkamah Konstitusi, merupakan peraturan yang bermuatan Undang-Undang karena telah memenuhi beberapa unsur muatan materi UndangUndang yaitu:

a. peraturan tersebut merupakan pengaturan lebih lanjut mengenai ketentuan UUD Tahun 1945.

b. Peraturan tersebut sebagai pemenuhan kebutuhan hukum dalam masyarakat.

PMK dengan demikian dapat dipetakan berdasarkan materi muatan yang terkandung didalamnya, yaitu PMK yang murni bermuatan materi PMK dan PMK berdasarkan materi muatan Undang-Undang. Berikut peneliti paparkan PMK setelah dilakukan pemetaan berdasarkan materi muatan yang terkandung di dalam masing-masing PMK.

Tabel 2

Pemetaan PMK berdasarkan materi muatannya.

\begin{tabular}{|l|l|l|}
\hline No. & Materi Muatan & \multicolumn{1}{|c|}{ PERATURAN MAHKAMAH KONSTITUSI } \\
\hline 1. & PMK & $\begin{array}{l}\text { Nomor 01/PMK/2003 tentang Tata Cara Pemilihan Ketua } \\
\text { dan Wakil Ketua Mahkamah Konstitusi }\end{array}$ \\
& $\begin{array}{l}\text { Nomor 02/PMK/2003 tentang Kode Etik dan Pedoman } \\
\text { Tingkah Laku Hakim Konstitusi }\end{array}$ \\
& $\begin{array}{l}\text { Nomor 03/PMK/2003 tentang Tata Tertib Persidangan } \\
\text { Pada Mahkamah Konstitusi republik Indonesia }\end{array}$ \\
& $\begin{array}{l}\text { Nomor 07/PMK/2005 Tentang Pemberlakuan Deklarasi } \\
\text { Kode Etik Dan Perilaku Hakim Konstitusi }\end{array}$ \\
\hline
\end{tabular}




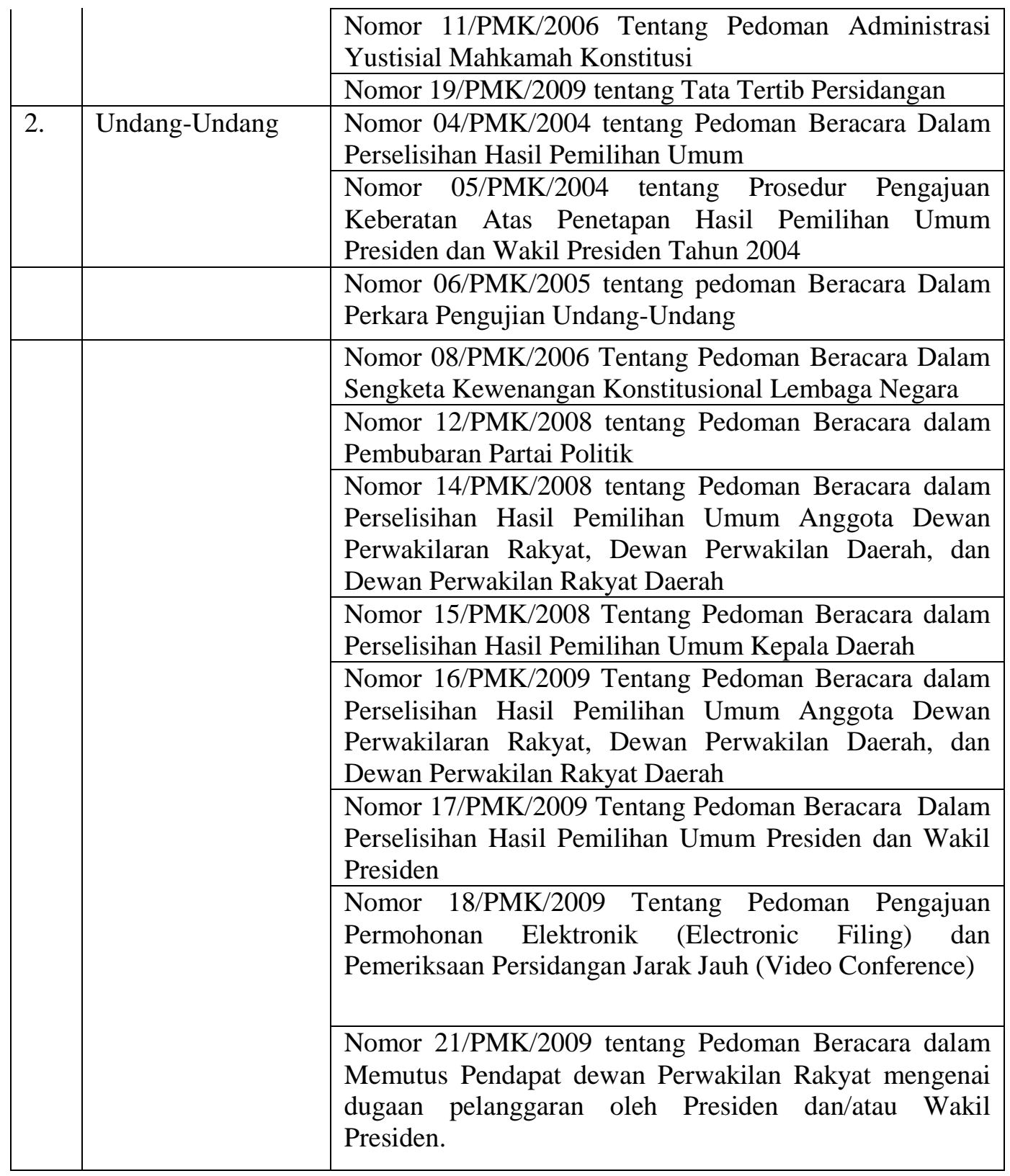

Berdasarkan Pemetaan PMK yang telah penulis sajikan diatas, maka sudah seharusnyalah PMK yang bermuatan Undang-Undang ditindak lanjuti lagi oleh pemegang kekuasaan legislasi untuk dapat menjadi UU Hukum Acara Mahkamah di Konstitusi demi terciptanya tatanan peraturan perundang-undangan yang baik berdasarkan Ilmu Perundangundangan.

\section{Penutup}

Sistem peraturan perundangundangan di Indonesia menghendaki keteraturan antara materi muatan dan jenis peraturan perundang-undangan. Penelitian ini memetakan bahwa Peraturan Mahkamah Konstitusi mempunyai kedudukan yang setingkat dengan peraturan yang dikeluarkan oleh lembaga tinggi negara berdasarkan UUD 1945. Selain itu, materi muatan Peraturan Mahkamah Konstitusi saat ini 
terpetakan ke dalam dua jenis materi muatan yang berbeda. Kedua jenis materi muatan ini seharusnya ditetapkan ke dalam jenis peraturan perundang-undangan sebagaimana mestinya.

\section{Daftar Pustaka}

Maruarar Siahaan, Hukum Acara Mahkamah Konstitusi Republik Indonesia, (Jakarta: Sinar Grafika, 2011).

Ismail Hasani \& A. Gani Abdullah, Pengantar Ilmu Perundang-Undangan (Jakarta: Fakultas Syariah dan Hukum UIN Syarif Hidayatullah Jakarta, 2006).

Rosjidi Ranggawidjaja, Pengantar Ilmu Perundang-undangan Indonesia, (Bandung: Mandar Maju,1998)
Bagir Manan dan Kuntana Magnar, Beberapa Masalah Hukum Tata Negara Indonesia, (Bandung: $\quad$ PT. Alumni, 1997).

Bagir Manan, Dasar-dasar Perundang-undangan

Indonesia, Ind Hill Co, Jakarta, 1992.

Maria Farida Indrati Soeprapto, Disertasi : Kedudukan dan Materi Muatan peraturan Pemerintah Pengganti Undang-Undang, peraturan Pemerintah, Dan Keputusan Presiden Dalam Penyelenggaraan Pemerintahan Negara Di Republik Indonesia, (Jakarta: Program Pascasarjana Fakultas Hukum Universitas Indonesia, 2002). 